\title{
The Protective Effect of Selenium on Chronic Zearalenone-Induced Reproductive System Damage in Male Mice
}

\author{
Miao Long ${ }^{1,2,+}$, Shuhua Yang ${ }^{1,+}$, Yuan Wang ${ }^{1}$, Peng Li $^{1}$, Yi Zhang ${ }^{1}$, Shuang Dong ${ }^{1}$, \\ Xinliang Chen ${ }^{1}$, Jiayi Guo ${ }^{1}$, Jianbin $\mathrm{He}^{1, *}$, Zenggui Gao ${ }^{2, *}$ and Jun Wang ${ }^{3, *}$ \\ 1 Key Laboratory of Zoonosis of Liaoning Province, College of Animal Science \& Veterinary Medicine, \\ Shenyang Agricultural University, Shenyang 110866, China; longjlau@126.com (M.L.); \\ yangshuhua0001@126.com (S.Y.); lm19781013@163.com (Y.W.); lipeng79625@163.com (P.L.); \\ sihuo12345@sohu.com (Y.Z.); DongS_FOCUS@163.com (S.D.); xinliang@syau.edu.cn (X.C.); \\ guoniuniu163@163.com (J.G.) \\ 2 Institute of Plant Immunology, College of Plant Protection College, Shenyang Agricultural University, \\ Shenyang 110866, China \\ 3 College of Animal Science and Technology, Jilin Agricultural University, Changchun 130118, China \\ * Correspondence: hejianbin69@163.com (J.H.); gaozenggui@sina.com (Z.G.); junwang2004@126.com (J.W.); \\ Tel./Fax: +86-24-8848-7156 (J.H.); +86-24-88487148 (Z.G.); +86-431-8453-2812 (J.W.) \\ + These authors contributed equally to this study.
}

Academic Editors: Claudio Santi and Luana Bagnoli

Received: 11 July 2016; Accepted: 5 December 2016; Published: 7 December 2016

\begin{abstract}
This study aims to explore the protective effect of selenium (Se) on chronic zearalenone (ZEN)-induced reproductive system damage in male mice and the possible protective molecular mechanism against this. The chronic ZEN-induced injury mouse model was established with the continuous intragastric administration of $40 \mathrm{mg} / \mathrm{kg}$ body mass (B.M.) ZEN for 28 days. Then, interventions with different doses $(0.1,0.2$, and $0.4 \mathrm{mg} / \mathrm{kg}$ B.M.) of Se were conducted on mice to analyse the changes in organ indexes of epididymis and testis, antioxidant capability of testis, serum level of testosterone, sperm concentration and motility parameters, and the expression levels of apoptosis-associated genes and blood testis barrier- (BTB) related genes. Our results showed that Se could greatly improve the ZEN-induced decrease of epididymis indexes and testis indexes. Results also showed that the decrease in sperm concentration, sperm normality rate, and sperm motility parameters, including percentage of motile sperm (motile), tropism percentage (progressive) and sperm average path velocity (VAP), caused by ZEN were elevated upon administration of the higher dose $(0.4 \mathrm{mg} / \mathrm{kg})$ and intermediate dose $(0.2 \mathrm{mg} / \mathrm{kg})$ of Se. Selenium also significantly reduced the content of malondialdehyde (MDA) but enhanced the activities of antioxidant enzymes superoxide dismutase (SOD) and glutathione peroxidase (GPx) in the testis tissue. Further research demonstrated that ZEN increased the level of mRNA expression of BCL2-associated X protein (Bax) and caspase 3 (Casp3), decreased the level of mRNA expression of B cell leukemia/lymphoma 2 (Bcl2), vimentin (Vim) and cadherin 2 (Cdh2), whereas the co-administration of Se reversed these gene expression levels. Our results indicated that high levels of Se could protect against reproductive system damage in male mice caused by ZEN and the mechanism might such be that Se improved mice antioxidant ability, inhibited reproductive cell apoptosis, and increased the decrease of BTB integrity-related genes caused by ZEN.
\end{abstract}

Keywords: selenium; zearalenone; reproductive; testis; male mice 


\section{Introduction}

Zearalenone (ZEN), a macrocyclic $\beta$-resorcyclic acid lactone, and a type of mycotoxin, is mainly produced by fungi of the Fusarium genus. F. culmorum [1]. Many reports revealed the risk of contamination is highest in cereal crops [2], meanwhile, silage, forage, and straw under humid conditions are also likely to contain ZEN [3]. Therefore, animals have easy access to this mycotoxin. Previous reviews report that ZEN has adverse effects on human and animal health [4]. When animals were fed a diet containing high levels of ZEN, various oestrogenic effects such as decreased fertility, increased embryolethal resorptions, reduced litter size, changed mass of adrenal, thyroid, and pituitary glands, and change in serum levels of progesterone and estradiol have been observed [4,5]. Moreover, ZEN can affect the quality of animal meat, cow milk, and chicken eggs [6]. However, the effect of ZEN is most pronounced on the reproductive system. Studies have shown that ZEN can result in breast tissue inflammation, oedematous uterus, ovarian cysts, and can cause abortion [7,8]. ZEN can also reduce male fertility. ZEN can cause testis damage to varying degrees, induce testicular atrophy and inflammation, and eventually result in decreasing sexual function with the number and quality of sperm decreased [9]. Moreover, ZEN have been found to be hepatotoxic [10], immunotoxic [11], genotoxic [12], and an enhancer of lipid peroxidation [13] in mammals. ZEN can remain and accumulate in the body for more than six months. These residues of ZEN in the body are harmful and can cause significant economic losses. Thus it can be seen that ZEN is one of the most harmful mycotoxins in the world. Therefore, how to reduce the toxicity of ZEN to animals has become a research focus. Studies demonstrated that the one of the mechanisms of ZEN toxicity is by inducing oxidative damage $[14,15]$ and causing cell apoptosis $[16,17]$. Therefore, we hypothesised that the substances that have anti-oxidant and anti-apoptotic ability might alleviate the damage caused by ZEN.

Selenium (Se) is one of the elements classified within the group of micronutrients that plays an important role in the health and performance of animals [18]. Selenium participates in the protection of cells against excess reactive oxygen species, and regulation of the immune and reproductive systems [19]. Studies showed that Se has a protective role in heat-induced apoptosis and oxidative stress in mice testes [20]. When a diet is deficient in Se, it can result in the occurrence of oxidative stress and apoptosis in chicken livers [21]. However, dietary supplementation with Se in roosters can reduce apoptosis of germ cells by regulating the mRNA expressions of apoptosis- and cell cycle-related genes in the testis during spermatogenesis [22]. Studies also showed that Se has a protective effect on ischaemia-reperfusion injury in a rat testis which caused testis cell apoptosis [23] and sodium selenite supplied in the diet could effectively inhibit aflatoxin B1-induced apoptosis and cell cycle blockage in renal cells of broilers [24]. Our previous study showed that Se has strong antioxidant properties without any toxic effect on either blood parameters or serum biochemical blood markers and was able to prevent most of the alterations induced by ZEN [25]. However, it is not clear whether or not Se can protect against reproductive system damage caused by ZEN in male mice: any protective mechanism also remains to be elucidated.

The blood testis barrier (BTB) is a structural barrier between the testicular fenestrated capillaries and the interior of the seminiferous tubules, which is a physical barrier in the testis to restrict the diffusion of various endogenous and exogenous toxic chemicals in mammals [26]. Exogenous chemicals can affect the intercellular connection structure of Sertoli cells, disintegrate and destroy the structure and function of BTB, and then cause reproductive damage [27]. During this process, related proteins such as claudin, cadherin, and catenin can play important roles in the control of the BTB [28]. If these protein expressions and (or) assemblies are changed, the BTB will change and toxins then readily enter the seminiferous epithelium $[29,30]$. Therefore, we hypothesised that ZEN could affect the expression of BTB-related genes, such as Cdh2 and Vim, then cause reproductive damage and Se could play its protective role by revising the expression of these genes. Therefore, in this study, we aimed to investigate the effects of Se on chronic ZEN-induced reproductive system damage in male mice and its possible protective mechanisms. 


\section{Results}

\subsection{Organ Indexes of Epididymis and Testis}

As shown in Table 1, the epididymis, and testis, indexes were both significantly decreased in the ZEN group dosed with $40 \mathrm{mg} / \mathrm{kg}$ ZEN for 28 days compared with the control group $(p<0.05)$. The epididymis, and testis, indexes in the Se groups and the Se + ZEN groups were significantly increased compared with the ZEN group $(p<0.05)$. Compared with the ZEN group, the epididymis, and testis, indexes in the Se + ZEN groups were significantly increased $(p<0.05)$. Moreover, the epididymis, and testis, indexes in 0.2 and $0.4 \mathrm{mg} / \mathrm{kg}$ Se groups were significantly higher than that in the control group $(p<0.05)$ (Table 1$)$.

Table 1. Effect of Se on organ indexes of epididymis and testis in mice induced by ZEN.

\begin{tabular}{ccc}
\hline Group & Organ Indexes of Epididymis (\%) & Organ Indexes of Testis (\%) \\
\hline Control & $0.108 \pm 0.006^{\mathrm{b}}$ & $0.393 \pm 0.012^{\mathrm{b}}$ \\
ZEN $(40 \mathrm{mg} / \mathrm{kg})$ & $0.073 \pm 0.004^{\mathrm{a}}$ & $0.305 \pm 0.006^{\mathrm{a}}$ \\
$0.1 \mathrm{mg} / \mathrm{kg} \mathrm{Se}$ & $0.112 \pm 0.003^{\mathrm{b}}$ & $0.418 \pm 0.009^{\mathrm{b}}$ \\
$0.2 \mathrm{mg} / \mathrm{kg} \mathrm{Se}$ & $0.120 \pm 0.008^{\mathrm{c}}$ & $0.433 \pm 0.010^{\mathrm{c}}$ \\
$0.4 \mathrm{mg} / \mathrm{kg} \mathrm{Se}$ & $0.125 \pm 0.005^{\mathrm{c}}$ & $0.440 \pm 0.007^{\mathrm{c}}$ \\
$0.1 \mathrm{mg} / \mathrm{kg} \mathrm{Se}+$ ZEN & $0.093 \pm 0.006^{\mathrm{b}}$ & $0.410 \pm 0.005^{\mathrm{b}}$ \\
$0.2 \mathrm{mg} / \mathrm{kg} \mathrm{Se}+$ ZEN & $0.095 \pm 0.005^{\mathrm{b}}$ & $0.416 \pm 0.006^{\mathrm{b}}$ \\
$0.4 \mathrm{mg} / \mathrm{kg} \mathrm{Se}+$ ZEN & $0.097 \pm 0.008^{\mathrm{b}}$ & $0.420 \pm 0.008^{\mathrm{b}}$ \\
\hline
\end{tabular}

${ }^{a-c}$ Means within the column with different letters are significantly different, $p<0.05$. Epididymis indexes: paired epididymides weight $(\mathrm{g}) /$ body weight $(\mathrm{g}) \times 100 \%$; Testis indexes: paired testes weight $(\mathrm{g}) /$ body weight $(\mathrm{g})$ $\times 100 \%$. ${ }^{a} p<0.05$ vs. control group, ${ }^{b} p<0.05$ vs. ZEN-treated group, ${ }^{c} p<0.05$ vs. control group and ZEN-treated group.

\subsection{Serum Level of Testosterone}

As shown in Table 2, compared with the control group, the serum testosterone contents were increased in $0.1,0.2$, and $0.4 \mathrm{mg} / \mathrm{kg}$ Se groups $(p<0.05)$. The serum level of testosterone was significantly decreased in the ZEN group compared with that in the control group $(p<0.05)$. When the mice were co-treated with different concentrations of $S e$, the serum levels of testosterone were increased in a dose-dependent manner. The levels of testosterone in groups co-treated with Se were significantly increased compared with the ZEN group $(p<0.05)$.

Table 2. Effect of Se on serum level of testosterone in mice induced by ZEN.

\begin{tabular}{cc}
\hline Group & Serum Level of Testosterone (ng/mL) \\
\hline Control & $7.443 \pm 1.064^{\mathrm{c}}$ \\
ZEN $(40 \mathrm{mg} / \mathrm{kg})$ & $0.153 \pm 0.008^{\mathrm{a}}$ \\
$0.1 \mathrm{mg} / \mathrm{kg} \mathrm{Se}$ & $9.973 \pm 1.107^{\mathrm{b}}$ \\
$0.2 \mathrm{mg} / \mathrm{kg} \mathrm{Se}$ & $10.404 \pm 1.139^{\mathrm{b}}$ \\
$0.4 \mathrm{mg} / \mathrm{kg} \mathrm{Se}$ & $11.967 \pm 1.007^{\mathrm{b}}$ \\
$0.1 \mathrm{mg} / \mathrm{kg} \mathrm{Se}+$ ZEN & $0.684 \pm 0.011^{\mathrm{b}}$ \\
$0.2 \mathrm{mg} / \mathrm{kg} \mathrm{Se}+$ ZEN & $0.933 \pm 0.005^{\mathrm{b}}$ \\
$0.4 \mathrm{mg} / \mathrm{kg} \mathrm{Se}+$ ZEN & $1.475 \pm 0.007^{\mathrm{b}}$ \\
\hline
\end{tabular}

a,b,c Means within the column with different letters are significantly different, $p<0.05$. ${ }^{a} p<0.05$ vs. control group, ${ }^{\mathrm{b}} p<0.05 \mathrm{vs}$. control group and ZEN-treated group, ${ }^{\mathrm{c}} p<0.05 \mathrm{vs}$. ZEN-treated group.

\subsection{Sperm Morphology and Deformity Rate}

As shown in Figure 1, the sperm showed normal morphologies in the control group (Figure 1A) and in the Se groups (Figure 1E-G). However, amorphous heads of sperms were seen in the ZEN group (Figure 1B-D) in forms such as: neck bending, having two tails, and having no head. Normal sperm 
appeared in the group co-administered with selenium yeast, although abnormal sperm occasionally appeared with a tail fold (Figure 1H-J).

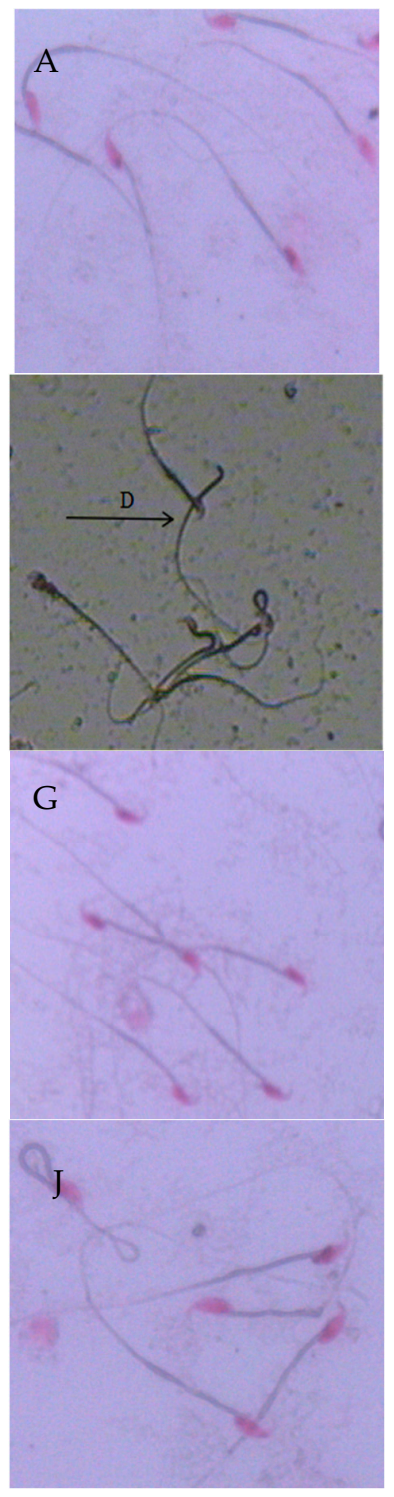

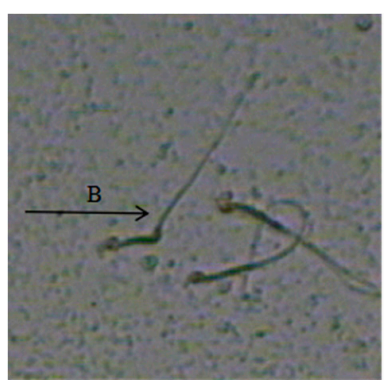

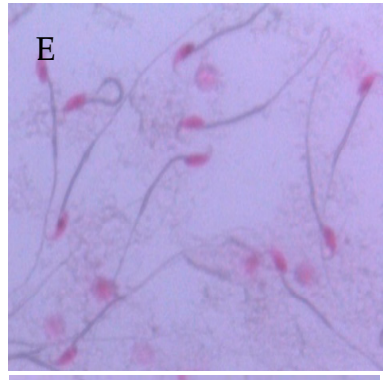

$\mathrm{H}$
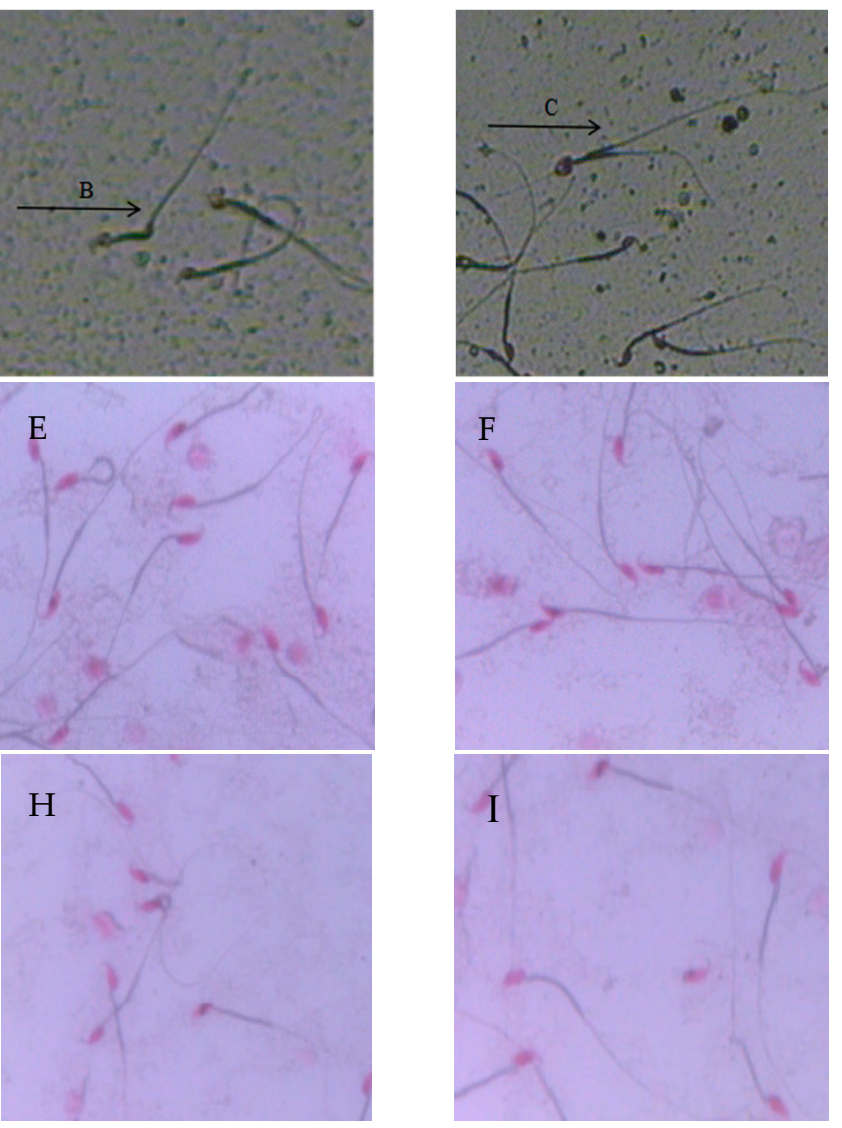

Figure 1. Effect of ZEN, different concentrations of selenium, and their co-treatment on morphology changes in mice sperm in mice testis (original magnification, $\times 400$ ). (A) control group; (B-D) ZEN $(40 \mathrm{mg} / \mathrm{kg}$ ) group, (E) $0.1 \mathrm{mg} / \mathrm{kg}$ Se treatment group; (F) $0.2 \mathrm{mg} / \mathrm{kg}$ Se treatment group; (G) $0.4 \mathrm{mg} / \mathrm{kg}$ Se treatment group; (H) $0.1 \mathrm{mg} / \mathrm{kg}$ Se + ZEN treatment group; (I) $0.2 \mathrm{mg} / \mathrm{kg}$ Se + ZEN treatment group; (J) $0.4 \mathrm{mg} / \mathrm{kg}$ Se + ZEN treatment group. Note: (B): neck bending; (C): two tails; (D): no head.

As shown in Table 3, there was no significant difference in sperm deformity rates between the control group and the Se groups $(p>0.05)$; however, compared with the control group, the abnormality rate in sperm was significantly higher than that in the ZEN group $(p<0.05)$. However, when the mice were co-treated with $0.4 \mathrm{mg} / \mathrm{kg}$ Se, the sperm abnormality rate decreased significantly $(p<0.05)$.

\subsection{Sperm Concentration and Motility Parameters}

As shown in Table 3, compared with the control group, the concentration of sperm in Se groups were not significantly different $(p>0.05)$. While the concentration of sperm in the ZEN group was significantly decreased compared with that in the control group $(p<0.05)$. However, when the 
mice were co-administered with $0.4 \mathrm{mg} / \mathrm{kg}$ Se, the decrease in sperm concentration caused by ZEN was greater $(p<0.05)$. Compared with the control group, the sperm motility parameters, such as the percentage of motile sperm (motile), tropism percentage (progressive), and sperm average path velocity (VAP) were not significantly different in Se groups $(p>0.05)$. However, compared with the control group, these parameters were all decreased in the ZEN group $(p<0.05)$. Compared with the ZEN group, the decrease in sperm motility and progressive tropism induced by ZEN were increased in the higher dose of Se $(0.4 \mathrm{mg} / \mathrm{kg})$ group $(p<0.05)$, meanwhile, the decrease of VAP induced by ZEN were also increased in the groups dosed with Se (both at $0.2 \mathrm{mg} / \mathrm{kg}$ and $0.4 \mathrm{mg} / \mathrm{kg})(p<0.05)$.

Table 3. Effect of Se on sperm deformity rate, sperm concentration and sperm motility in mice induced by ZEN.

\begin{tabular}{|c|c|c|c|c|c|}
\hline Group & $\begin{array}{c}\text { Sperm Deformity } \\
\text { Rate }(\%)\end{array}$ & $\begin{array}{l}\text { Sperm Number } \\
\text { (million/mL) }\end{array}$ & Motile (\%) & Progressive $(\%)$ & $\mathrm{VAP}(\mu \mathrm{m} / \mathrm{s})$ \\
\hline Control & $12.22 \pm 2.11^{\mathrm{a}}$ & $21.49 \pm 1.58^{\mathrm{a}}$ & $90.41 \pm 2.17^{a}$ & $15.33 \pm 2.77^{a}$ & $75.42 \pm 4.34^{\mathrm{a}}$ \\
\hline ZEN (40 mg/kg) & $24.56 \pm 4.20^{b}$ & $10.06 \pm 0.55^{b}$ & $38.52 \pm 1.30^{b}$ & $6.78 \pm 1.49^{b}$ & $48.72 \pm 3.33^{b}$ \\
\hline $0.1 \mathrm{mg} / \mathrm{kg} \mathrm{Se}$ & $13.58 \pm 3.66^{\mathrm{a}}$ & $22.42 \pm 1.80^{\mathrm{a}}$ & $90.36 \pm 1.85^{\mathrm{a}}$ & $15.03 \pm 1.74^{\mathrm{a}}$ & $74.32 \pm 2.86^{\mathrm{a}}$ \\
\hline $0.2 \mathrm{mg} / \mathrm{kg} \mathrm{Se}$ & $13.23 \pm 3.26^{\mathrm{a}}$ & $21.51 \pm 1.88^{\mathrm{a}}$ & $91.54 \pm 1.80^{\mathrm{a}}$ & $15.65 \pm 1.88^{a}$ & $76.73 \pm 2.56^{a}$ \\
\hline $0.4 \mathrm{mg} / \mathrm{kg} \mathrm{Se}$ & $12.56 \pm 3.41^{\mathrm{a}}$ & $22.98 \pm 1.61^{\mathrm{a}}$ & $92.30 \pm 1.63^{\mathrm{a}}$ & $16.38 \pm 1.93^{\mathrm{a}}$ & $80.16 \pm 2.21^{a}$ \\
\hline $0.1 \mathrm{mg} / \mathrm{kg} \mathrm{Se}+\mathrm{ZEN}$ & $20.84 \pm 3.52^{b}$ & $12.33 \pm 0.91^{b}$ & $81.56 \pm 1.39^{c}$ & $6.66 \pm 1.04^{b}$ & $54.33 \pm 1.59^{b}$ \\
\hline $0.2 \mathrm{mg} / \mathrm{kg} \mathrm{Se}+\mathrm{ZEN}$ & $20.46 \pm 3.09^{b}$ & $16.06 \pm 1.23^{c}$ & $82.82 \pm 1.31^{c}$ & $7.28 \pm 1.61^{b}$ & $70.43 \pm 1.69^{a}$ \\
\hline $0.4 \mathrm{mg} / \mathrm{kg} \mathrm{Se}+\mathrm{ZEN}$ & $13.45 \pm 2.52^{\mathrm{a}}$ & $20.15 \pm 1.43^{\mathrm{a}}$ & $88.36 \pm 1.53^{a}$ & $14.46 \pm 1.47^{\mathrm{a}}$ & $72.40 \pm 1.58^{a}$ \\
\hline
\end{tabular}

\subsection{Testis Antioxidant Parameters}

As shown in Table 4, the contents of MDA in testis tissue of mice in the ZEN group were significantly higher than that in the control group $(p<0.05)$. Compared with the control group, the MDA levels were not significantly different in the 0.1, 0.2, and $0.4 \mathrm{mg} / \mathrm{kg}$ Se groups $(p>0.05)$. However, the MDA contents in the $0.4 \mathrm{mg} / \mathrm{kg}$ Se + ZEN group were significantly different compared with those in the ZEN group $(p<0.05)$. Compared with the control group, the activities of SOD and GPx were all increased in the $0.1,0.2$, and $0.4 \mathrm{mg} / \mathrm{kg}$ Se groups. However, compared with the control group, the activities of SOD and GPx were all decreased in the ZEN (40 mg/kg) group; however, the activities of SOD and GPx were elevated when the mice were co-administered with Se. At higher doses of Se $(0.4 \mathrm{mg} / \mathrm{kg})$, the activities of SOD and GPx were significantly different compared with those of the ZEN group $(p<0.05)$.

Table 4. Effect of Se on testis antioxidant parameters in mice induced by ZEN.

\begin{tabular}{cccc}
\hline Group & MDA (nmol/mgprot) & SOD (U/mgprot) & GPx (mg/gprot) \\
\hline control & $0.437 \pm 0.067^{\mathrm{b}}$ & $55.149 \pm 0.788^{\mathrm{b}}$ & $47.118 \pm 3.878^{\mathrm{b}}$ \\
ZEN $(40 \mathrm{mg} / \mathrm{kg})$ & $1.255 \pm 0.039^{\mathrm{c}}$ & $35.006 \pm 0.450^{\mathrm{c}}$ & $29.112 \pm 1.80^{\mathrm{c}}$ \\
$0.1 \mathrm{mg} / \mathrm{kg} \mathrm{Se}$ & $0.510 \pm 0.057^{\mathrm{b}}$ & $65.429 \pm 0.800^{\mathrm{a}}$ & $55.460 \pm 3.45^{\mathrm{b}}$ \\
$0.2 \mathrm{mg} / \mathrm{kg} \mathrm{Se}$ & $0.526 \pm 0.068^{\mathrm{b}}$ & $67.713 \pm 1.088^{\mathrm{a}}$ & $57.421 \pm 3.088^{\mathrm{b}}$ \\
$0.4 \mathrm{mg} / \mathrm{kg} \mathrm{Se}$ & $0.683 \pm 0.037^{\mathrm{b}}$ & $68.998 \pm 2.310^{\mathrm{a}}$ & $75.460 \pm 1.230^{\mathrm{a}}$ \\
$0.1 \mathrm{mg} / \mathrm{kg} \mathrm{Se}+$ ZEN & $1.182 \pm 0.021^{\mathrm{c}}$ & $56.630 \pm 1.319^{\mathrm{b}}$ & $29.604 \pm 3.319^{\mathrm{c}}$ \\
$0.2 \mathrm{mg} / \mathrm{kg} \mathrm{Se}+$ ZEN & $0.981 \pm 0.038^{\mathrm{c}}$ & $59.006 \pm 1.031^{\mathrm{b}}$ & $32.421 \pm 3.301^{\mathrm{b}}$ \\
$0.4 \mathrm{mg} / \mathrm{kg} \mathrm{Se}+$ ZEN & $0.710 \pm 0.020^{\mathrm{b}}$ & $60.050 \pm 1.43^{\mathrm{b}}$ & $45.625 \pm 3.432^{\mathrm{b}}$ \\
\hline
\end{tabular}

a-c Means within the column with different letters are significantly different, $p<0.05 .{ }^{a} p<0.05$ vs. control group and ZEN-treated group, ${ }^{\mathrm{b}} p<0.05$ vs. ZEN-treated group, ${ }^{\mathrm{c}} p<0.05$ vs. control group. MDA: malondialdehyde; GPx: glutathione peroxidase; SOD: superoxide dismutase. 


\subsection{Effect on the mRNA Expression of Bax, Casp3, and Bcl2}

As shown in Figures 2 and 3, compared with the control group, the mRNA expression of Casp3 and Bax were increased in the ZEN group $(p<0.05)$. Although the mRNA expression of Casp3 and Bax were all increased in groups with different concentrations of Se, there was no difference with that in the control group $(p>0.05)$. When the mice were co-treated with $0.4 \mathrm{mg} / \mathrm{kg} \mathrm{Se}$, the mRNA expressions of Casp 3 and Bax were decreased compared with that in the ZEN group $(p<0.05)$. The results showed that giving mice a higher level of Se could inhibit the expression of proapoptotic genes Casp3 and Bax which were enhanced by ZEN. As shown in Figure 4, compared with the control group, the mRNA expressions of $B c l 2$ were all increased at different concentrations of Se $(p<0.05)$. However, the mRNA expression of $B c l 2$ decreased in the ZEN group $(p<0.05)$. When the mice were co-treated with $0.1,0.2$, and $0.4 \mathrm{mg} / \mathrm{kg}$ Se, respectively, the mRNA expressions of $B c l 2$ were all increased whereas before they were inhibited by ZEN.

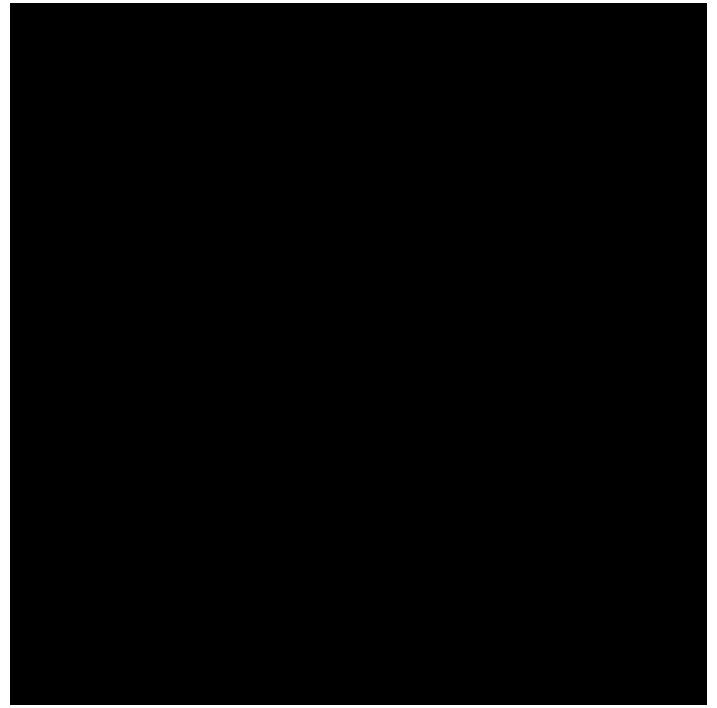

Figure 2. Effect of ZEN, different concentrations of Se and their co-treatment groups on the relative mRNA expression of Casp3 in mice testicular tissue. Values are mean $\pm \mathrm{SE}$ of twenty mice in each group. ${ }^{a, b}$ Means with different letters are significantly different, $p<0.05$. ${ }^{a} p<0.05$ vs. control group, ${ }^{\mathrm{b}} p<0.05$ vs. ZEN-treated group.

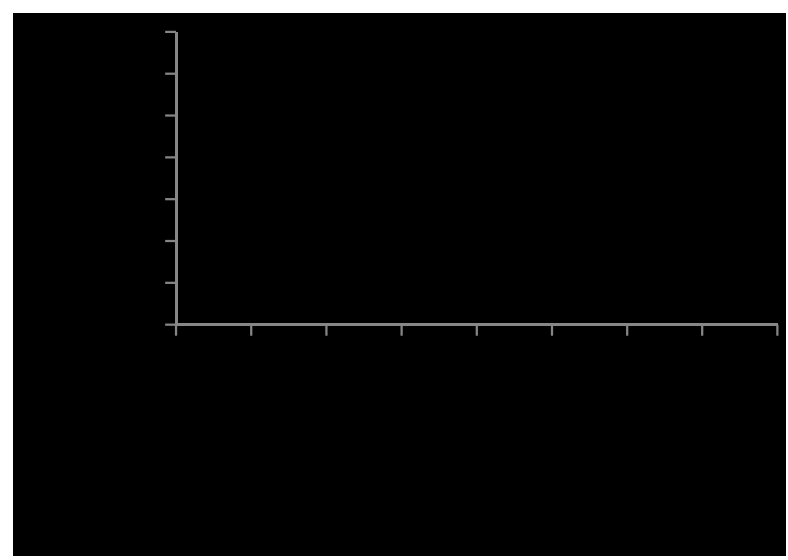

Figure 3. Effect of ZEN, different concentration of Se and their co-treatment on the relative mRNA expression of Bax in mice testicular tissue. Values are mean $\pm \mathrm{SE}$ of twenty mice in each group. $\mathrm{a}, \mathrm{b}$ Means with different letters are significantly different, $p<0.05$. ${ }^{\mathrm{a}} p<0.05$ vs. control group, ${ }^{\mathrm{b}} p<0.05$ vs. ZEN-treated group. 


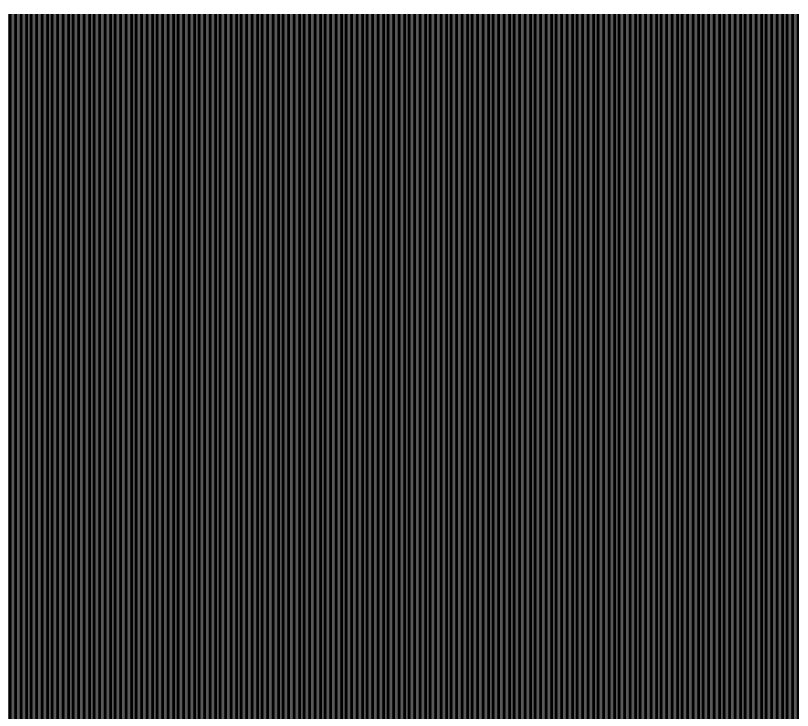

Figure 4. Effect of ZEN, different concentration of Se and their co-treatment on the relative mRNA expression of $B c l 2$ in mice testicular tissue. Values are mean $\pm \mathrm{SE}$ of twenty mice in each group. ${ }^{\mathrm{a}-\mathrm{c}}$ Means with different letters are significantly different, $p<0.05$. ${ }^{\mathrm{a}} p<0.05$ vs. control group and ZEN-treated group, ${ }^{\mathrm{b}} p<0.05$ vs. ZEN-treated group, ${ }^{\mathrm{c}} p<0.05$ vs. control group.

\subsection{Effect on the mRNA Expression of Vim and Cdh2}

As shown in Figures 5 and 6, compared with the control group, the mRNA expressions of Vim and $C d h 2$ were both decreased in the ZEN group $(p<0.05)$. Meanwhile, the mRNA expression of Vim and $C d h 2$ were all increased at different concentrations of Se: there were difference with that in the control group $(p<0.05)$. When mice were co-treated with $0.1,0.2$, and $0.4 \mathrm{mg} / \mathrm{kg}$ Se, the mRNA expressions of $\operatorname{Vim}$ and $C d h 2$ were increased compared with that in the ZEN group $(p<0.05)$. The results showed that giving mice the Se could improve the gene expressions of $\mathrm{Vim}$ and $\mathrm{Cdh} 2$ which were otherwise decreased by ZEN.

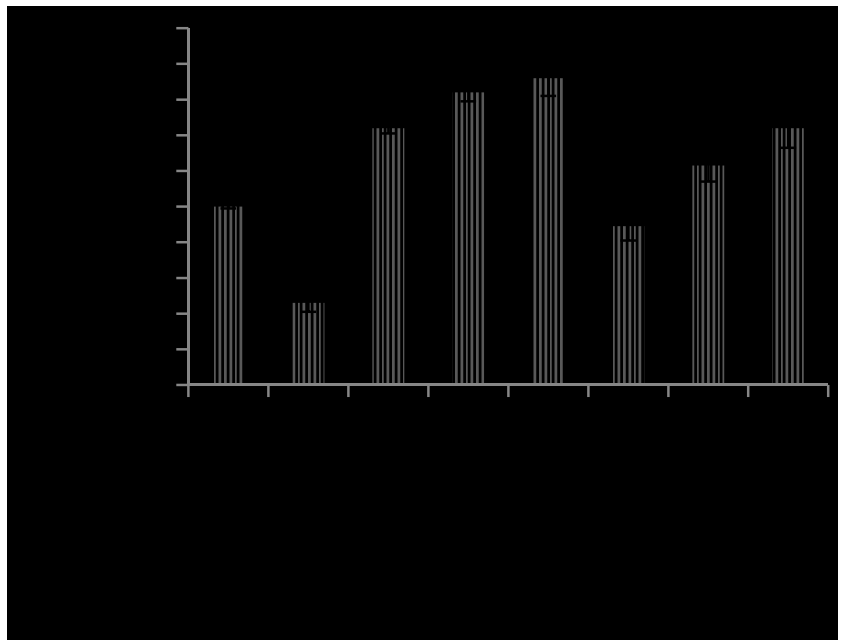

Figure 5. Effect of ZEN, different concentration of Se and their co-treatment on the relative mRNA expression of Vim in mice testicular tissue. Values are mean $\pm \mathrm{SE}$ of twenty mice in each group. ${ }^{a-c}$ Means with different letters are significantly different, $p<0.05$. ${ }^{a} p<0.05$ vs. ZEN-treated group, ${ }^{\mathrm{b}} p<0.05$ vs. control group and ZEN-treated group, ${ }^{\mathrm{c}} p<0.05$ vs. control group. 


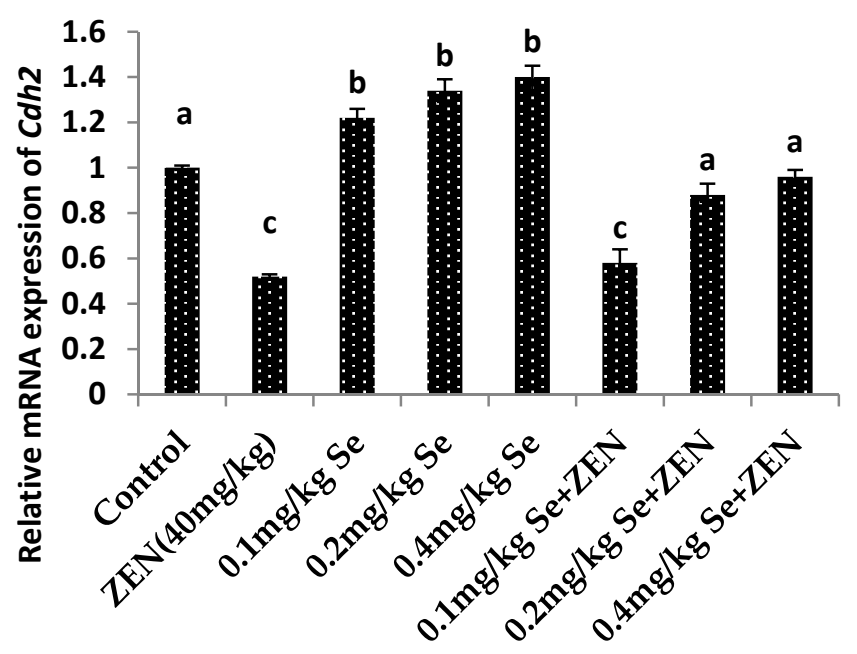

Figure 6. Effect of ZEN, different concentration of selenium yeast and their co-treatment on the relative mRNA expression of $C d h 2$ in mice testicular tissue. Values are mean $\pm \mathrm{SE}$ of twenty mice in each group. ${ }^{a-c}$ Means with different letters are significantly different, $p<0.05$. ${ }^{a} p<0.05$ vs. ZEN-treated group,

${ }^{\mathrm{b}} p<0.05$ vs. control group and ZEN-treated group, ${ }^{\mathrm{c}} p<0.05$ vs. control group.

\section{Discussion}

In recent years, many studies have demonstrated that ZEN is harmful to animal health, and especially to reproductive function [31]. However, there are few reports of the effects of ZEN on the male reproductive system. This study extends the knowledge of ZEN toxicity on the male reproductive system.

Our results showed that after the mice were given $40 \mathrm{mg} / \mathrm{kg}$ ZEN (B.M.) for 28 days, the serum testosterone levels were decreased significantly, the concentration of sperm, the percentage of motile sperm motility (motile), tropism percentage (progressive), and sperm average path velocity (VAP) were also decreased significantly, while the rate of sperm deformity was increased. The results indicated that ZEN caused damage to the Leydig cells as testosterone is mainly secreted thereby [32]. Moreover, the results demonstrated that ZEN induced the damage of sperm in mice in vivo, which were proved by in vitro studies where ZEN was shown to reduce the hCG-stimulated testosterone synthesis of mouse Leydig cells at concentrations ranging from $10^{-8}$ to $10^{-4} \mathrm{M}$ : this leads to a spermatogenetic disorder [33].

Studies have provided evidence that environmental toxins can induce oxidative stress, and are involved in reproductive toxicity. Furthermore, recent reports show that the toxicity of ZEN is not only due to its oestrogenicity alone [34,35]: it is demonstrated that ZEN can induce oxidative damage, which is likely to be one of the main pathways of ZEN toxicity $[35,36]$. Our results showed that when the mice were given $40 \mathrm{mg} / \mathrm{kg}$ ZEN (B.M.) for 28 days, the contents of MDA were increased and the activities of SOD and GPx were decreased, which results were in agreement with previous studies [37]. These results showed that ZEN could inhibit the antioxidant capacity of the body by reducing the efficacy and amount of key antioxidative enzymes.

Many studies have shown that ZEN could induce tissue cell apoptosis as a result of damage caused by oxidative stress [16]. Our results showed that ZEN up-regulated the proapoptotic Bax and Casp 3 mRNA expression and down-regulated the inhibiting apoptosis gene Bcl2 mRNA expression. These results may also give the proof that ZEN can induce tissue cell apoptosis and thus make this the main mechanism of ZEN toxicity.

Selenium, as an antioxidant, can eliminate many oxygen free radicals, reduce oxidative stress damage to the body, and improve the body's antioxidant ability and immune function $[38,39]$. However, whether Se can reduce the toxicity of ZEN and its effect on the reproductive system, and damage thereto, in male mice remains unclear. We used selenium yeast as an organic Se supplement because 
yeast is a good carrier for organic Se, and selenium yeast has both a high physiological activity and low toxicity [40]. Our results showed that when the mice were given 0.1 or $0.2 \mathrm{mg} / \mathrm{kg}$ Se for 28 days alone, the testis indexes were, to some extent, improved, which results indicated that Se had a certain function in promoting testis development. After co-administration of $0.4 \mathrm{mg} / \mathrm{kg}$ Se for 28 days, Se reduced the damage effect of ZEN on the testis and epididymis and alleviated the toxicity of ZEN on sperm. In our study, co-treatment with Se was able to improve the concentration of testosterone and oestrogen indicating that Se could protect testicular tissue. The protective mechanism might be because Se has a strong antioxidant ability to protect it from damage by lipid peroxidation, thus resulting in it inhibiting ZEN-induced testis tissue cell apoptosis. To the best of our knowledge, this is the first reported time in which Se was seen to have the ability to protect against chronic ZEN-induced reproductive system damage in male mice. When the mice were co-treated with Se, the activities of SOD and GPx were significantly increased. Previous studies showed that Se can enhance the decrease of antioxidative enzyme activities, such as SOD and GPx as induced by lithium [41] and cadmium [42]. Our results indicate that Se can elevate the decrease of antioxidant enzyme activities caused by ZEN. Se can reduce oxidative damage of testis caused by ZEN. Combined with previous studies, our results also demonstrated that Se has the ability to activate genes whose expression results in the formation of the enzymes involved in the Phase II xenobiotic metabolising pathway-the detoxification stage thereof-and slows down the synthesis of enzymes in Phase I [19,43]. At the same time, these results also explained the mechanism by which Se reduced the rate of sperm deformity, and increased the concentration of sperm and sperm motility.

The BTB is a physical barrier in the testis that restricts the diffusion of various endogenous and exogenous toxic chemicals in mammals [26]. Some proteins play important roles in the maintenance of BTB integrity. The Vim protein affords physical support to the BTB. The CDH2 protein has adhesion molecules and exhibits junctional adhesion, and is mainly distributed between the Sertoli cells in the basal portion: it is involved in cell adhesion and signal transduction [44]. The tightness of connection between the germ cells and the Sertoli cells is one of the important indexes used to evaluate damage to the BTB [45]. A previous study shows that ZEN could significantly reduce the mRNA expression of Vim and Cdh2 in vitro [46], indicating that ZEN could destroy the BTB. We indicated that ZEN could impair the BTB by a widening of the intercellular tight junction. This research also showed that ZEN decreased the gene expression of Vim and Cdh2 two key proteins affecting BTB integrity. Meanwhile, some researchers have proved that ZEN can affect the cytoskeletal structure and specific secretory functions [46] and induce apoptosis and necrosis in rat Sertoli cells in vitro [17]. Therefore, our results indicated that Se could protect the testis from damage via increasing the mRNA expression levels of the two genes, resulting in a retention of BTB integrity. However, it still needs further research to study the effect of Se on the expression of the other genes related to BTB and to examine the protein(s) related to BTB by using immunohistochemistry to illustrate the protective mechanism of Se against BTB damage.

Many studies have demonstrated that Se can protect against hepatocellular oxidative damage induced by lipopolysaccharides [47], renal damage caused by some metallic elements [48], and Aflatoxin B1 [49]. Previous studies also have demonstrated that Se appears to be mediated through its anti-apoptosis and anti-oxidative effects to protect against testis damage caused by ischaemia-reperfusion [23], cisplatin [50], electromagnetic radiation [51], and carbimazole [52]. Our results demonstrated that Se could inhibit testis tissue cells apoptosis caused by ZEN. However, which signal pathway plays the most important role in decreasing the toxic effect of ZEN by Se should be further studied in vitro. Furthermore, although the beneficial effects of Se are well known, it can also cause metabolic disorders. In the future, we will study other effects on other reproductive organ systems of male mice that may be adversely affected by treatment with Se. 


\section{Experimental Section}

\subsection{Animals}

Some 160 male Kunming mice ( $20 \pm 2$ g, aged 4 weeks) were purchased from Liao Ning Chang Sheng Biotechnology Co., Ltd. (Benxi, China). The mice were bred in a room at a temperature ranging from 22 to $24{ }^{\circ} \mathrm{C}$ and the mice were subjected to 12-hour light/dark cycles at a relative humidity of between $40 \%$ to $60 \%$. Water and the controlled diet were available on a minimum ad libitum basis for the mice. The mice were acclimatized for one week after transportation. The experiments have been approved by the Ethics Committee for Laboratory Animal Care (Animal Ethics Procedures and Guidelines of the People's Republic of China) for the use of Shenyang Agricultural University, China. (Permit No. SYXK<Liao $>2011-0001$ ).

\subsection{Chemicals}

ZEN was obtained from Sigma (St. Louis, MO, USA), which was prepared at a concentration of $200 \mathrm{mg} / \mathrm{mL}$ as a stock solution by using diethyl sulphoxide and the solution was stored at $-20^{\circ} \mathrm{C}$. The working solution was obtained by dispensing the stock solution into the $0.9 \%$ physiological saline, and the concentration of ZEN was $1 \mathrm{mg} / \mathrm{mL}$ : at this concentration, the DMSO content was $0.5 \%$. Selenium yeast was obtained from the Angel Yeast Co. Ltd. (Wuhan, China; with a Se content of $2000 \mathrm{mg} / \mathrm{kg}$ ). The kits used for measuring GPx, SOD, and MDA activities were obtained from Nanjing Jiancheng Bioengineering Institute (Nanjing, China); the SYBR green RT-PCR kit (Takara, Japan), and DAPI (Sigma Aldrich, St. Louis, MO, USA) were also used. The primers for Casp3, Bax, Bcl2, and Actb were synthesised and purified by Sangon Biotech (Shanghai, China); moreover, the preservation solution of RNA samples and the kits for total animal RNA extraction were obtained from Sangon Biotech Co., Ltd., while the kits for Reversion Aid First Strand cDNA Synthesis were purchased from MBI Fermentas (Burlington, ON, Canada). The Iodine $\left[{ }^{125} \mathrm{I}\right]$ Testosterone Radioimmunoassay Kit was purchased from Beijing North Biological Technology Research Institute Co., Ltd. (Beijing, China).

\subsection{Experimental Design and Treatment}

The control group $(n=20)$ : the mice were dosed by intragastric administration with physiological saline, daily, for 28 days.

The ZEN group $(n=20)$ : the mice were dosed by intragastric administration with a $40 \mathrm{mg} / \mathrm{kg}$ dose of ZEN (B.M.) $\left(40 \mathrm{mg} / \mathrm{kg}-8 \%\right.$ of $\left.\mathrm{LD}_{50}\right)$, which was based on other preliminary experiments $[53,54]$, daily for 28 days.

The $0.1 \mathrm{mg} / \mathrm{kg}$ Se group $(n=20)$ : the mice were given $0.1 \mathrm{mg} / \mathrm{kg}$ Se B.M. by intragastric administration with a $0.05 \mathrm{~g}$ dose of selenium yeast (containing $2 \mathrm{~g} / \mathrm{kg}$ Se) diluted with physiological saline, daily, for 28 days.

The $0.2 \mathrm{mg} / \mathrm{kg}$ Se group $(n=20)$ : the mice were given $0.2 \mathrm{mg} / \mathrm{kg}$ Se B.W. by intragastric administration with a $0.1 \mathrm{~g}$ dose of selenium yeast (containing $2 \mathrm{~g} / \mathrm{kg}$ Se) diluted with physiological saline, daily, for 28 days.

The $0.4 \mathrm{mg} / \mathrm{kg}$ Se group $(n=20)$ : the mice were given $0.2 \mathrm{mg} / \mathrm{kg}$ Se B.W. by intragastric administration with a $0.2 \mathrm{~g}$ dose of selenium yeast (containing $2 \mathrm{~g} / \mathrm{kg}$ Se) diluted with physiological saline, daily, for 28 days.

The $0.1 \mathrm{mg} / \mathrm{kg}$ Se + ZEN group $(n=20)$ : after given $0.1 \mathrm{mg} / \mathrm{kg}$ Se B.W. by intragastric administration with a $0.05 \mathrm{~g}$ dose of selenium yeast at 9:00 a.m., the mice were given a $40 \mathrm{mg} / \mathrm{kg}$ dose of ZEN (B.W.) in the same way at 15:00 p.m., daily, for 28 days.

The $0.2 \mathrm{mg} / \mathrm{kg}$ Se + ZEN group $(n=20)$ : after given $0.2 \mathrm{mg} / \mathrm{kg}$ Se B.W. by intragastric administration with a $0.1 \mathrm{~g}$ dose of selenium yeast at 9:00 a.m., at 9:00 a.m., the mice were given a $40 \mathrm{mg} / \mathrm{kg}$ dose of ZEN (B.W.) in the same way at 15:00 p.m., daily, for 28 days. 
The $0.4 \mathrm{mg} / \mathrm{kg} \mathrm{Se}+$ ZEN group $(n=20)$ : after given $0.4 \mathrm{mg} / \mathrm{kg}$ Se B.W. by intragastric administration with a $0.2 \mathrm{~g}$ dose of selenium yeast at 9:00 a.m., the mice were given a $40 \mathrm{mg} / \mathrm{kg}$ dose of ZEN (B.W.) in the same way at 15:00 p.m., daily, for 28 days.

At $24 \mathrm{~h}$ after the last pre-treatment, the mice were weighed and blood was collected from the endocanthion. The mice were then sacrificed by cervical dislocation. From this sample, the serum was separated by centrifugation and stored at $-80{ }^{\circ} \mathrm{C}$ until assayed. From each group we randomly selected five mice to excise and weigh both testes and epididymides. Then, the other mice testes tissues were weighed and then stored at $-80{ }^{\circ} \mathrm{C}$ for further use in the experiments, and the other mice epididymis were immediately put into $2 \mathrm{~mL} 0.9 \%$ saline at $37^{\circ} \mathrm{C}$ to extract sperm after being isolated from each mouse.

\subsection{Parameters}

\subsubsection{Epididymis, and Testis, Indexes}

After the last administration (and a delay of approximately $24 \mathrm{~h}$ ), the body, the paired epididymides, and paired testes were weighed. The organ index was given by:

$$
\text { Organ index }=(\text { organ mass }(\mathrm{g}) / \text { body mass }(\mathrm{g})) \times 100 \%
$$

\subsubsection{Serum Testosterone Levels in Mice}

The radioimmunoassay method was used to detect serum testosterone levels. The details of the determination procedures followed the manufacturer's instructions for the Iodine $\left[{ }^{125} \mathrm{I}\right]$ Testosterone Radioimmunoassay Kit.

\subsubsection{Sperm Deformity Rate}

A drop of fresh semen and a drop of $1 \%$ eosin solution were mixed on a glass slide and covered with a cover-slip. After $30 \mathrm{~s}$, the semen was observed under an optical microscope at $\times 400$ magnification. The sperm morphology was observed according to the dead sperm which were stained red and the rate of sperm abnormality was calculated.

\subsubsection{Sperm Concentration and Motility}

After dilution of the semen, the sperm concentration was calculated by blood cell counting plate method. The computer assisted sperm analysis system (CASA) was used to analyse sperm motility and activity mode such as motility, progressive tropism, and average path velocity (VAP).

\subsubsection{Antioxidant}

In the experiment, the content of MDA, and the activities of GPx and SOD were examined to analyse the oxidant levels of the mice testis. SOD, MDA, and GPx assay kits were used to carry out the analysis. The details of all determination procedures followed the manufacturer's instructions for the commercial kits.

\subsection{Gene Expression}

The total RNA of the testis was extracted using TRIzol reagent. Then, the purity of the total RNA was measured via the quotient for OD at $260 / 280 \mathrm{~nm}$. The mRNA was then reverse transcribed into cDNA using a MBI Fermentas PrimeScript RT reagent kit. The cDNA was adopted as the template for quantitative RT-PCR analysis. An ABI 7500 real-time PCR system and the SYBR Green PCR Kit were used to conduct real-time PCR. Each sample was measured in triplicate.

For the qRT-PCR reactions, $2 \mu \mathrm{L}$ product of $\mathrm{cDNA}, 0.4 \mu \mathrm{L}$ reverse primer, $0.4 \mu \mathrm{L}$ forward primer, $10 \mu \mathrm{L} 2 \times$ SYBR $^{\circledR}$ Premix Ex Taq ${ }^{\mathrm{TM}}, 6.8 \mu \mathrm{L}$ of RNase-freewater, and $0.4 \mu \mathrm{L}$ ROX Reference Dye II $(50 \times)$ were used. The conditions under which the PCR reaction was conducted included: at the initial stage, 
denaturing at $95^{\circ} \mathrm{C}$ for $5 \mathrm{~min}$, and then denaturing at $95^{\circ} \mathrm{C}$ for $10 \mathrm{~s}$, annealing at $60{ }^{\circ} \mathrm{C}$ for $5 \mathrm{~s}$, and extension at $60^{\circ} \mathrm{C}$ for $34 \mathrm{~s}$. The amount of template was measured based on the standard curve for such a quantitative analysis. The gene expressions of Casp3, Bcl2, and Bax were analysed, and Actb was used as a housekeeping gene. The primers of Casp3, Bcl2, Bax, Vim, Cdh2, and Actb are listed in Table 5. The results were analysed by using the $2^{-\Delta \Delta C T}$ assay.

Table 5. Primers for real-time PCR analyses.

\begin{tabular}{|c|c|c|c|c|}
\hline Gene & Primer & Primer Sequences $\left(5^{\prime}-3^{\prime}\right)$ & Product Size/bp & Accession No. \\
\hline \multirow[t]{2}{*}{ Casp3 } & Forward & CTGACTGGAAAGCCGAAACTC & $189 \mathrm{bp}$ & NM_009810.2 \\
\hline & Reverse & CGACCCGTCCTTTGAATTTCT & & \\
\hline \multirow[t]{2}{*}{ Bax } & Forward & CAGGATGCGTCCACCAAGAA & $197 \mathrm{bp}$ & NM_007527.3 \\
\hline & Reverse & GCAAAGTAGAAGAGGGCAACCAC & & \\
\hline \multirow[t]{2}{*}{ Bcl2 } & Forward & GCTACCGTCGTCGTGACTTCGC & $147 \mathrm{bp}$ & NM_177410.2 \\
\hline & Reverse & CCCCACCGAACTCAAAGAAGG & & \\
\hline \multirow[t]{2}{*}{$\operatorname{Vim}$} & Forward & GATCAGCTCACCAACGACAA & $120 \mathrm{bp}$ & NM_011701.4 \\
\hline & Reverse & GCTTTCGGCTTCCTCTCTCT & & \\
\hline \multirow[t]{2}{*}{$C d h 2$} & Forward & AGGACCCTTTCCTCAAGAGC & $117 \mathrm{bp}$ & AB008811.1 \\
\hline & Reverse & ATAATGAAGATGCCCGTTGG & & \\
\hline \multirow[t]{2}{*}{$A c t b$} & Forward & CTGTCCCTGTATGCCTCTG & $221 \mathrm{bp}$ & BC_138614.1 \\
\hline & Reverse & TTGATGTCACGCACGATT & & \\
\hline
\end{tabular}

\subsection{Statistical Analysis}

Results were presented as the mean \pm standard error $(X \pm S E)$. Firstly, one-way ANOVA was used to assess the significance of differences among mean values. Afterwards, a StudentNewman-Keuls (SNK) post hoc test, or the least significant difference (LSD) multiple, was used via pair-wise comparisons. In addition, SPSS 17 software (IBM, Almon, NY, USA) was used to carry out all statistical tests. Mean values were proven to be significantly different at $p<0.05$.

\section{Conclusions}

In summary, Se can improve the ZEN-induced decrease of the concentration of sperm, the sperm motility parameters, and reduce the rate of occurrence of deformities in sperm. The protection mechanism might be such that Se could inhibit the oxidative stress and apoptosis of reproductive-related cells induced by ZEN and Se could play its protective role by increasing the gene expression of Vim and Cdh2.

Acknowledgments: This work was financially supported by the National Natural Science Foundation of China (Grants No. 31201961; Grants No. 31302152 and Grants No. 31640084); China Postdoctoral Science Foundation Project Grants (2014M551125); and the General Program of Liaoning Provincial Department of Education Science Research (L2014561).

Author Contributions: Jun Wang, Miao Long, Jianbin He and Shuhua Yang conceived and designed the experiments; Yuan Wang, Xin-Liang Chen, and Shuang Dong performed the experiments; Yi Zhang and Jiayi Guo analyzed the data; Peng Li and Zenggui Gao contributed materials and revised the manuscript; Jun Wang revised the manuscript; Miao Long wrote the paper.

Conflicts of Interest: The authors declare no conflict of interest.

\section{References}

1. Hestbjerg, H.; Nielsen, K.F.; Thrane, U.; Elmholt, S. Production of trichothecenes and other secondary metabolites by Fusarium culmorum and Fusarium equiseti on common laboratory media and a soil organic matter agar: An ecological interpretation. J. Agric. Food. Chem. 2002, 50, 7593-7599. [CrossRef] [PubMed]

2. Pleadin, J.; Sokolović, M.; Perši, N.; Zadravec, M.; Jaki, V.; Vulić, A. Contamination of maize with deoxynivalenol and zearalenone in Croatia. Food Control. 2012, 28, 94-98. [CrossRef] 
3. Placinta, C.M.; D'Mello, J.P.F.; Mac Donald, A.M.C. A review of worldwide contamination of cereal grains and animal feed with Fusarium mycotoxins. Anim. Feed Sci. Technol. 1999, 78, 21-37. [CrossRef]

4. Zinedine, A.; Soriano, J.M.; Molto, J.C.; Manes, J. Review on the toxicity, occurrence, metabolism, detoxification, regulations and intake of zearalenone: An oestrogenic mycotoxin. Food Chem. Toxicol. 2007, 45, 1-18. [CrossRef] [PubMed]

5. Gajęcka, M.; Woźny, M.; Brzuzan, P.; Zielonka, Ł.; Gajęcki, M. Expression of CYPscc and 3 $\beta$-HSD mRNA in bitches ovary after long-term exposure to zearalenone. Bull. Vet. Inst. Pulawy 2011, 55, 777-780.

6. Winkler, J.; Kersten, S.; Meyer, U.; Engelhardt, U.; Dänicke, S. Residues of zearalenone (ZEN), deoxynivalenol $(\mathrm{DON})$ and their metabolites in plasma of dairy cows fed Fusarium contaminated maize and their relationships to performance parameters. Food. Chem. Toxicol. 2014, 65, 196-204. [CrossRef] [PubMed]

7. Fink-Gremmels, J.; Malekinejad, H. Clinical effects and biochemical mechanisms associated with exposure to the mycoestrogen zearalenone. Anim. Feed Sci. Technol. 2007, 137, 326-341. [CrossRef]

8. Gajęcki, M. Zearalenone: Undesirable substances in feed. Pol. J. Vet. Sci. 2002, 5, 117-122. [PubMed]

9. Ben Salah-Abbes, J.; Abbes, S.; Houas, Z.; Abdel-Wahhab, M.A.; Oueslati, R. Zearalenone induces immunotoxicity in mice: possible protective effects of radish extract (Raphanus sativus). J. Pharm. Pharmacol. 2008, 60, 761-770. [CrossRef] [PubMed]

10. Conkova, E.; Laciakova, A.; Pastorova, B.; Seidel, H.; Kovac, G. The effect of zearalenone on some enzymatic parameters in rabbits. Toxicol. Lett. 2001, 121, 145-149. [CrossRef] [PubMed]

11. Hueza, I.M.; Raspantini, P.C.; Raspantini, L.E.; Latorre, A.O.; Górniak, S.L. Zearalenone, an estrogenic mycotoxin, is an immunotoxic compound. Toxins (Basel) 2014, 6, 1080-1095. [CrossRef] [PubMed]

12. Lioi, M.B.; Santoro, A.; Barbieri, R.; Salzano, S.; Ursini, M.V. Ochratoxin and zearalenone: A comparative study on genotoxic effects and cell death induced in bovine lymphocytes. Mutat. Res. 2004, 557, 19-24. [CrossRef] [PubMed]

13. Abid-Essefi, S.; Ouanes, Z.; Hassen, W.; Baudrimont, I.; Creppy, E.E.; Bacha, H. Cytotoxicity, inhibition of DNA and protein syntheses and oxidative damage in cultured cells exposed to zearalenone. Toxicol. In Vitro 2004, 18, 467-474. [CrossRef] [PubMed]

14. Marin, D.E.; Pistol, G.C.; Neagoe, I.V.; Calin, L.; Taranu, I. Effects of zearalenone on oxidative stress and inflammation in weanling piglets. Food. Chem. Toxicol. 2013, 58, 408-415. [CrossRef] [PubMed]

15. Liu, M.; Gao, R.; Meng, Q.; Zhang, Y.; Bi, C.; Shan, A. Toxic effects of maternal zearalenone exposure on intestinal oxidative stress, barrier function, immunological and morphological changes in rats. PLoS ONE 2014, 9, e106412. [CrossRef] [PubMed]

16. Ben Salem, I.; Prola, A.; Boussabbeh, M.; Guilbert, A.; Bacha, H.; Abid-Essefi, S.; Lemaire, C. Crocin and Quercetin protect HCT116 and HEK293 cells from Zearalenone-induced apoptosis by reducing endoplasmic reticulum stress. Cell Stress Chaperones 2015, 20, 927-938. [CrossRef] [PubMed]

17. Xu, M.L.; Hu, J.; Guo, B.P.; Niu, Y.R.; Xiao, C.; Xu, Y.X. Exploration of intrinsic and extrinsic apoptotic pathways in zearalenone-treated rat sertoli cells. Environ. Toxicol. 2015. [CrossRef] [PubMed]

18. Mehdi, Y.; Dufrasne, I. Selenium in Cattle: A Review. Molecules 2016, 21, 545. [CrossRef] [PubMed]

19. Kieliszek, M.; Błażejak, S. Current knowledge on the importance of selenium in food for living organisms: A review. Molecules 2016, 21, 609. [CrossRef] [PubMed]

20. Kaur, S.; Bansal, M.P. Protective role of dietary-supplemented selenium and vitamin E in heat-induced apoptosis and oxidative stress in mice testes. Andrologia 2015, 47, 1109-1119. [CrossRef] [PubMed]

21. Yao, L.; Du, Q.; Yao, H.; Chen, X.; Zhang, Z.; Xu, S. Roles of oxidative stress and endoplasmic reticulum stress in selenium deficiency-induced apoptosis in chicken liver. Biometals 2015, 28, 255-265. [CrossRef] [PubMed]

22. Song, R.; Yao, X.; Shi, L.; Ren, Y.; Zhao, H. Effects of dietary selenium on apoptosis of germ cells in the testis during spermatogenesis in roosters. Theriogenology 2015, 84, 583-588. [CrossRef] [PubMed]

23. Kara, Ö.; Sari, E.; Akşit, H.; Yay, A.; Akşit, D.; Dönmez, M.I. Effects of selenium on ischaemia-reperfusion injury in a rat testis model. Andrologia 2016. [CrossRef] [PubMed]

24. Yu, Z.; Wang, F.; Liang, N.; Wang, C.; Peng, X.; Fang, J.; Cui, H.; Jameel Mughal, M.; Lai, W. Effect of selenium supplementation on apoptosis and cell cycle blockage of renal cells in broilers fed a diet Containing Aflatoxin B1. Biol. Trace Elem. Res. 2015, 68, 242-251. [CrossRef] [PubMed]

25. Long, M.; Yang, S.; Zhang, W.; Zhang, Y.; Li, P.; Guo, Y.; Wang, Y.; Chen, X.; He, J. The influence of selenium yeast on hematological, biochemical and reproductive hormone level changes in Kunming Mice following acute exposure to zearalenone. Biol. Trace Elem. Res. 2016, 174, 362-368. [CrossRef] [PubMed] 
26. Fan, Y.; Liu, Y.; Xue, K.; Gu, G.; Fan, W.; Xu, Y. Diet-induced obesity in male C57BL/6 mice decreases fertility as a consequence of disrupted blood-testis barrier. PLoS ONE 2015, 10, e0120775. [CrossRef] [PubMed]

27. Bekheet, S.H.M. Cadmium chloride rapidly alters both BTB tight junction proteins and germ cells in young rat testes. Egypt. Acad. J. Biol. Sci. 2010, 2, 59-74.

28. Jiang, X.H.; Bukhari, I.; Zheng, W.; Yin, S.; Wang, Z.; Cooke, H.J.; Shi, Q.H. Blood-testis barrier and spermatogenesis: lessons from genetically-modified mice. Asian J. Androl. 2014, 16, 572-580. [PubMed]

29. Li, M.W.; Mruk, D.D.; Lee, W.M.; Cheng, C.Y. Connexin 43 is critical to maintain the homeostasis of the blood-testis barrier via its effects on tight junction reassembly. Proc. Natl. Acad. Sci. USA 2010, 107, 17998-18003. [CrossRef] [PubMed]

30. Carette, D.; Perrard, M.H.; Prisant, N.; Gilleron, J.; Pointis, G.; Segretain, D.; Durand, P. Hexavalent chromium at low concentration alters Sertoli cell barrier and connexin 43 gap junction but not claudin- 11 and $N$-cadherin in the rat seminiferous tubule culture model. Toxicol. Appl. Pharmacol. 2013, 268, 27-36. [CrossRef] [PubMed]

31. Minervini, F.; Dell'Aquila, M.E. Zearalenone and reproductive function in farm animals. Int. J. Mol. Sci. 2008, 9, 2570-2584. [CrossRef] [PubMed]

32. Iliadou, P.K.; Tsametis, C.; Kaprara, A.; Papadimas, I.; Goulis, D.G. The Sertoli cell: Novel clinical potentiality. Hormones (Athens) 2015, 14, 504-514. [CrossRef] [PubMed]

33. Yang, J.; Zhang, Y.; Wang, Y.; Cui, S. Toxic effects of zearalenone and $\alpha$-zearalenol on the regulation of steroidogenesis and testosterone production in mouse Leydig cells. Toxicol. In Vitro 2007, 21, 558-565. [CrossRef] [PubMed]

34. El Golli Bennour, E.; Bouaziz, C.; Ladjimi, M.; Renaud, F.; Bacha, H. Comparative mechanisms of zearalenone and ochratoxin A toxicities on cultured HepG2 cells: Is oxidative stress a common process? Environ. Toxicol. 2009, 24, 538-548. [CrossRef] [PubMed]

35. Hassen, W.; Ayed-Boussema, I.; Oscoz, A.A.; Lopez Ade, C.; Bacha, H. The role of oxidative stress in zearalenone-mediated toxicity in Hep G2 cells: Oxidative DNA damage, gluthatione depletion and stress proteins induction. Toxicology 2007, 232, 294-302. [CrossRef] [PubMed]

36. El Golli-Bennour, E.; Bacha, H. Hsp70 expression as biomarkers of oxidative stress: Mycotoxins' exploration. Toxicology 2011, 287, 1-7. [CrossRef] [PubMed]

37. Ben Salah-Abbès, J.; Abbès, S.; Abdel-Wahhab, M.A.; Oueslati, R. Raphanus sativus extract protects against Zearalenone induced reproductive toxicity, oxidative stress and mutagenic alterations in male Balb/c mice. Toxicon 2009, 53, 525-533. [CrossRef] [PubMed]

38. Vetvicka, V.; Vetvickova, J. Addition of Selenium Improves Immunomodulative Effects of Glucan. N. Am. J. Med. Sci. 2016, 8, 88-92. [CrossRef] [PubMed]

39. Hao, S.; Hu, J.; Song, S.; Huang, D.; Xu, H.; Qian, G.; Gan, F.; Huang, K. Selenium Alleviates Aflatoxin B1-Induced Immune Toxicity through Improving Glutathione Peroxidase 1 and Selenoprotein S Expression in Primary Porcine Splenocytes. J. Agric. Food. Chem. 2016, 64, 1385-1393. [CrossRef] [PubMed]

40. Griffiths, J.C.; Matulka, R.A.; Power, R. Acute and subchronic toxicity studies on Sel-Plex, a standardized, registered highselenium yeast. Int. J. Toxicol. 2006, 25, 465-476. [CrossRef] [PubMed]

41. Kiełczykowska, M.; Kocot, J.; Kurzepa, J.; Lewandowska, A.; Żelazowska, R.; Musik, I. Could selenium administration alleviate the disturbances of blood parameters caused by lithium administration in rats? Biol. Trace Elem. Res. 2014, 158, 359-364. [CrossRef] [PubMed]

42. Liu, L.; Yang, B.; Cheng, Y.; Lin, H. Ameliorative effects of selenium on cadmium-induced oxidative stress and endoplasmic reticulum stress in the chicken kidney. Biol. Trace Elem. Res. 2015, 167, 308-319. [CrossRef] [PubMed]

43. Drutel, A.; Archambeaud, F.; Caron, P. Selenium and the thyroid gland: More good news for clinicians. Clin. Endocrinol. 2013, 78, 155-164. [CrossRef] [PubMed]

44. Newton, S.C.; Blaschuk, O.W.; Millette, C.F. N-cadherin mediates Sertoli cell- spermatogenic cell adhesion. Dev. Dyn. 1993, 197, 1-13. [CrossRef] [PubMed]

45. Daniel, G. Cyr. Connexins and pannexins Coordinating cellular communication in the testis and epididymis. Spermatogenesis 2011, 1, 325-338.

46. Zheng, W.; Pan, S.; Wang, G.; Wang, Y.J.; Liu, Q.; Gu, J.; Yuan, Y.; Liu, X.Z.; Liu, Z.P.; Bian, J.C. Zearalenone impairs the male reproductive system functions via inducing structural and functional alterations of sertoli cells. Environ. Toxicol. Pharmacol. 2016, 42, 146-155. [CrossRef] [PubMed] 
47. Taskin, E.; Dursun, N. The protection of selenium on adriamycin-induced mitochondrial damage in rat. Biol. Trace Elem. Res. 2012, 147, 165-171. [CrossRef] [PubMed]

48. El-Sharaky, A.; Newairy, A.; Badreldeen, M.; Eweda, S.; Sheweita, S. Protective role of selenium against renal toxicity induced by cadmium in rats. Toxicology 2007, 235, 185-193. [CrossRef] [PubMed]

49. Liang, N.; Wang, F.; Peng, X.; Fang, J.; Cui, H.; Chen, Z.; Lai, W.; Zhou, Y.; Geng, Y. Effect of Sodium Selenite on Pathological Changes and Renal Functions in Broilers Fed a Diet Containing Aflatoxin $\mathrm{B}_{1}$. Int. J. Environ. Res. Public Health 2015, 12, 11196-11208. [CrossRef] [PubMed]

50. Simsek, N.; Koc, A.; Karadeniz, A.; Yildirim, M.E.; Celik, H.T.; Sari, E.; Kara, A. Ameliorative effect of selenium in cisplatin-induced testicular damage in rats. Acta Histochem. 2016, 118, 263-270. [CrossRef] [PubMed]

51. Saygin, M.; Caliskan, S.; Ozguner, M.F.; Gumral, N.; Comlekci, S.; Karahan, N. Impact of L-carnitine and Selenium Treatment on Testicular Apoptosis in Rats Exposed to $2.45 \mathrm{GHz}$ Microwave Energy. West. Indian Med. J. 2015, 64, 55-61. [PubMed]

52. Sakr, S.A.; Mahran, H.A.; Nofal, A.E. Effect of selenium on carbimazole-induced testicular damage and oxidative stress in albino rats. J. Trace Elem. Med. Biol. 2011, 25, 59-66. [CrossRef] [PubMed]

53. Boeira, S.P.; Funck, V.R.; Filho, C.B.; Del'Fabbro, L.; de Gomes, M.G.; Donato, F.; Royes, L.F.; Oliveira, M.S.; Jesse, C.R.; Furian, A.F. Lycopene protects against acute zearalenone-induced oxidative, endocrine, inflammatory and reproductive damages in male mice. Chem. Biol. Interact. 2015, 230, 50-57. [CrossRef] [PubMed]

54. Boeira, S.P.; Filho, C.B.; Del'Fabbro, L.; Roman, S.S.; Royes, L.F.; Fighera, M.R. Lycopene treatment prevents hematological, reproductive and histopathological damage induced by acute zearalenone administration in male Swiss mice. Exp. Toxicol. Pathol. 2014, 66, 179-185. [CrossRef] [PubMed]

Sample Availability: Not Available.

(c) 2016 by the authors; licensee MDPI, Basel, Switzerland. This article is an open access article distributed under the terms and conditions of the Creative Commons Attribution (CC-BY) license (http://creativecommons.org/licenses/by/4.0/). 